\title{
Triterpenes esterified with fatty acid isolated from Pouteria macahensis T.D. Penn (Sapotaceae) leaves
}

\author{
Santos, R. R. C.; Conceição, A. O.; Lula, I. S.; Oliveira, F. F.; Oliveira, R. A.*
}

Rev. Virtual Quim., 2018, 10 (5), 1327-1334. Data de publicação na Web: 1 de outubro de 2018

http://rvq.sbq.org.br

\section{Triterpenos esterificados com ácidos graxos isolados das folhas de Pouteria macahensis T.D. Penn (Sapotaceae)}

Resumo: Pouteria macahensis é uma espécie endêmica da Mata Atlântica, de ocorrência em áreas restritas. Nesse trabalho é apresentado o estudo fitoquímico do extrato etanólico das folhas de $P$. machaensis, coletadas em Itacaré, Bahia, Brasil. Folhas secas e trituradas foram submetidas à extração exaustiva com hexano e em seguida etanol. $O$ estudo do extrato etanólico permitiu a identificação de seis triterpenos pentacíclicos esterificados com ácidos graxos: mistura de behenato e erucato de $3 \beta$-erithrodiol, palmitoleato de $3 \beta$ erithrodiol e mistura de behenato, erucato e palmitoleato de ácido $3 \beta$-betulínico. As identificações estruturais foram baseadas nas técnicas espectroscópicas de IV, RMN de ${ }^{1} \mathrm{H} \mathrm{e}{ }^{13} \mathrm{C}$ (1D e 2D) e dos ésteres de ácidos graxos, após reação de transesterificação, através da análise por cromatografia a gás. A presença desses compostos pode estar associada à localização das espécies na Mata Atlântica, em terreno arenoso e com grande incidência de sol.

Palavras-chave: Mata Atlântica, Lacuna macahensis, transesterificação.

\begin{abstract}
Pouteria macahensis is an endemic species of the Atlantic Rainforest, which occurs in restricted regions. This work presents the phytochemical study of the leaf ethanolic extract from $P$. macahensis, collected in Itacaré, Bahia, Brazil. Dry and ground leaves were submitted to exhaustive extraction in hexane, followed by ethanol. The ethanolic extract yielded six fatty acid esters of pentacyclic triterpenes: a mixture of $3 \beta$-erythrodiol behenate and erucate; $3 \beta$-erythrodiol palmitoleate; and the mixture of $3 \beta$-betulinic acid behenate, erucate, and palmitoleate. The structural identifications were based on the spectroscopic techniques of $I R,{ }^{1} \mathrm{H}$, and ${ }^{13} \mathrm{C}$ NMR (1D and 2D), as well as the esters of fatty acids, after the reaction of transesterification and gas chromatography analysis. The presence of these compounds can be associated with the localization of the species in the Atlantic Rainforest, in a sandy terrain and in a region with constant sunshine.
\end{abstract}

Keywords: Atlantic Rainforest, Lacuna macahensis, transesterification.

\footnotetext{
* Universidade Estadual de Santa Cruz, Departamento de Ciências Exatas e Tecnológicas, Rodovia Jorge Amado, Km-16, Salobrinho, CEP 45662-900, Ilhéus-BA, Brasil.

$M$ rosilene@uesc.br

DOI: $\underline{10.21577 / 1984-6835.20180091}$
} 


\title{
Triterpenes esterified with fatty acid isolated from Pouteria macahensis T.D. Penn (Sapotaceae) leaves
}

\author{
Randilla R. C. dos Santos, ${ }^{a}$ Aline O. Conceição, ${ }^{b}$ Ivana S. Lula, ${ }^{c}$ Fernando F. \\ de Oliveira, ${ }^{a}$ Rosilene A. de Oliveira ${ }^{\mathrm{a}, *}$ \\ a Universidade Estadual de Santa Cruz, Departamento de Ciências Exatas e Tecnológicas, \\ Ilhéus, Brasil.

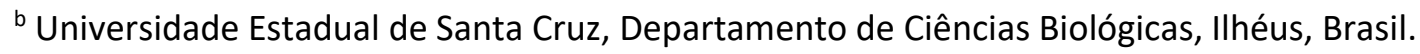 \\ c Universidade Federal de Minas Gerais, Departamento de Química, Belo Horizonte, Brasil. \\ * rosilene@uesc.br
}

Recebido em 3 de abril de 2018. Aceito para publicação em 25 de setembro de 2018

\section{Introduction}

2. Materials and Methods

2.1. General procedures

2.2. Plant material

2.3. Extraction and isolation of compounds

2.4. Spectroscopy data

\section{Results and Discussion \\ 4. Conclusions}

\section{Introduction}

Pentacyclic triterpenes, such as friedelanes, oleananes, ursanes, and lupanes are commonly isolated in plant species; however, triterpenes esterified with long chain fatty acids are rarer. Triterpenes are considered to be chemotaxonomic markers from the Sapotaceae family, which consists of 53 genera and approximately 1,100 species, distributed in tropical and subtropical regions. $^{1}$

Ethnopharmacological studies of the Sapotaceae family indicate that the Pouteria genus is among the most widely studied. ${ }^{2}$ This genus, which is most commonly found in South America, is comprised of 122 species, which 50 are endemic to the Atlantic Rainforest. In Brazil, there are 11 genera and 231 species distributed throughout the states of Amazônia, Bahia, Espírito Santo, Rio de Janeiro, and São Paulo. ${ }^{3}$

In the genera of Gambeya, Pradosia, and Manilkara (Sapotaceae family), triterpenes esterified with the acetyl group and with long chain fatty acids were isolated; however, some researchers no identify the long chain. Erythrodiol, $\beta$ and $\alpha$-amyrin esters were isolated from $G$. africana fruits, $M$. bidentate and $M$. subsericea (Mart). ${ }^{4-6}$ From the leaves 
of Pradosia huberi (Ducke) were isolated long chain fatty acids derived from erythrodiol and betulinic acid. ${ }^{7}$

The Pouteria genus, in the bark of $P$. campechiana, yielded esters derived from erythrodiol, oleanolic acid, and betulinic acid. ${ }^{8}$ From the $P$. torta leaves, palmitate and erythrodiol were isolated..$^{9}$

Pouteria macahensis T.D. Penn (a synonym for Lacuma macahensis Glaz), popular name "Maçaranduba-mirim", is an endemic tree to the Atlantic Rainforest, distributed along the Brazilian coastline in the states of Alagoas, Bahia, Espírito Santo, and Rio de Janeiro. ${ }^{3}$ Due Pouteria to be a genus of wood plants, the occurrence of this species is more and more scarce, especially in urban centers and its surroundings. The present study offers a contribution to the chemical study of the $P$. macahaensis species, through the isolation of substances from its leaf ethanolic extract. To the best of our knowledge, this is the first chemical study conducted with the leaves of this species.

\section{Materials and Methods}

\subsection{General Procedures}

For Thin Layer Chromatography (TLC) and Preparative Thin Layer Chromatography (Prepative TLC) were used silica gel Vetec ${ }^{\circledR} 60$ $\mathrm{G}$, and to Column Chromatography (CC) were used silica gel Merck ${ }^{\circledR} 60(0.063-0.200 \mathrm{~mm})$. Spectra of de ${ }^{1} \mathrm{H}$ and ${ }^{13} \mathrm{C}$ NMR (1D and 2D) were acquired in the Bruker Avance ${ }^{\circledR}$ CRX400 device, using TMS as a reference. The IR spectra were recorded in the Perkin Elmer ${ }^{\circledR}$ 400 device, and melting points were recorded in the Fisatom ${ }^{\circledR}$ 430D Capillary Fusion Point without correction. To characterize the fatty acid esters chain bonded to triterpenes, the transesterification methodology was adopted, according to that proposed by Mendes. ${ }^{10}$ The analysis of the fatty acid esters was performed in the Varian Saturm 3800 gas chromatography $(G C)$, equipped with FID,
Carbowax fused-silica capillary column ( $30 \mathrm{~m} x$ $0.25 \mathrm{~mm} \times 0.25 \mu \mathrm{m})$, He 5.0 with a flow of 1.0 $\mathrm{mL} \mathrm{min}^{-1}$, and temperatures: injector $220^{\circ} \mathrm{C}$, detector $240{ }^{\circ} \mathrm{C}$. The initial temperature of the column was $60{ }^{\circ} \mathrm{C}$, raised by $5{ }^{\circ} \mathrm{C} \mathrm{min}-1$ until reaching $200{ }^{\circ} \mathrm{C}$, and was then maintained at this temperature for five minutes. The FAME mixture, $\mathrm{C}_{8}-\mathrm{C}_{22}$, (Supelco - USA; catalog 47801- Lot: LC00126) was used to identify the chemical composition of the esters through the comparison of the retention times.

\subsection{Plant material}

P. macahensis was collected in the town of Itacaré, Bahia, Brazil, in September 2015 (coordinates 40¹5'53.0"S 38 59'59.6"W) and was identified by Luiz Alberto Mattos Silva and José Lima da Paixão. The specimen voucher was deposited in the Herbarium of the State University of Santa Cruz, logged under protocol number 21,469 , and the leaves were dried in a forced ventilation oven.

\subsection{Extraction and isolation}

The plant material $(2100 \mathrm{~g})$ was submitted to exhaustive maceration in hexane and ethanol at room temperature. The ethanolic extract (80 g) was chromatographed in $\mathrm{CC}$, using as eluents $\mathrm{Hex}, \mathrm{CHCl}_{3}, \mathrm{AcOEt}$, and $\mathrm{EtOH}$ (pure and in mixtures), yielding 34 fractions. After TLC analyses (Hex, $\mathrm{CHCl}_{3}$ 4:6), the samples were joined in 15 groups (G1-G15). Group G4 (1.9767 g) was treated with acetone, resulting in a solid; the remainder of the material ( $1.4567 \mathrm{~g}$ ) was chromatographed in $\mathrm{CC}$ using the eluents $\mathrm{Hex}$ and $\mathrm{CHCl}_{3}$ (pure and in mixtures), supplying 21 fractions, grouped by TLC (DCM, $\mathrm{CHCl}_{3} 2: 8$ ) in 4 groups (A-D). Group B (0.1820 g) was treated with acetone and recrystallized with methanol, supplying a mixture of compounds $\mathbf{1} \mathbf{a}-\mathbf{b}$ $(0.0215 \mathrm{~g})$. This mixture of compounds $\mathbf{1} \mathbf{a}-\mathbf{b}$ was transesterified with $\mathrm{MeOH} / \mathrm{MeONa}$, leading to substance $2(7 \mathrm{mg})$. The filtrated group $\mathrm{B}$ was submitted to preparative TLC, using $\mathrm{CH}_{2} \mathrm{Cl}_{2} / \mathrm{CHCl}_{3}$ (8:2), allowing for the 
isolation of compound 3 (0.0267 g). Group G6 $(1.2342 \mathrm{~g})$ was treated with acetone and recrystallized with $\mathrm{MeOH}$, resulting in a mixture of compounds $4 \mathrm{a}-\mathrm{c}(0.0291 \mathrm{~g})$. The mixture of compounds $4 a-c$, after transesterification, resulted in compound $\mathbf{5}$ ( 8 $\mathrm{mg})$.

\subsection{Spectroscopic data}

$3 \beta$-erythrodiol behenate and erucicate (1ab): Amorphous white solid (MeOH), M.p: 118$121^{\circ} \mathrm{C}$; IR $\left(\mathrm{KBr}, \mathrm{cm}^{-1}\right)$ : 3474, 2952, 2863, 1735 , $1465,1384 .{ }^{1} \mathrm{H}$ NMR $\left(400 \mathrm{MHz}, \mathrm{CDCl}_{3}\right) \delta: 0.86$ $\left(6 \mathrm{H}, s, \mathrm{CH}_{3}-29\right.$ and $\left.\mathrm{CH}_{3}-30\right) ; 0.87\left(3 \mathrm{H}, \mathrm{s}, \mathrm{CH}_{3}-\right.$ 24); 0.89 (3H, s, $\left.\mathrm{CH}_{3}-23\right) ; 0.94\left(3 \mathrm{H}, s, \mathrm{CH}_{3}-25\right)$; $0.95\left(3 \mathrm{H}, \mathrm{s}, \mathrm{CH}_{3}-26\right) ; 1,16$ (3H, s, $\left.\mathrm{CH}_{3}-27\right) ; 1.25$ (nH, s, H-C(n-fatty acid); $1.55-1.98(\mathrm{nH}, m, \mathrm{H}-$ $\mathrm{C}\left(\right.$ n-alkyl); $2.28\left(2 \mathrm{H}, t, J=7.4 \mathrm{~Hz}, \mathrm{H}-2^{\prime}\right) ; 3.21$ $(1 \mathrm{H}, d, J=10.9 \mathrm{~Hz}, \mathrm{H}-28 \mathrm{a}) ; 3.54(1 \mathrm{H}, d, J=$ $10.9 \mathrm{~Hz}, \mathrm{H}-28 \mathrm{~b}) ; 4.5(1 \mathrm{H}, m, \mathrm{H}-3) ; 5.17(1 \mathrm{H}, t$, $J=3.2 \mathrm{~Hz}, \mathrm{H}-12) ; 5.29\left(1 \mathrm{H}, \mathrm{br}, \mathrm{H}-9^{\prime}\right) .{ }^{13} \mathrm{C}$ NMR (100 MHz, $\mathrm{CDCl}_{3}$ ): Table 1.

3ß-erythrodiol (2): White powder (EtOH), M.p: $228-230{ }^{\circ} \mathrm{C}$. IR $\left(\mathrm{KBr}, \mathrm{cm}^{-1}\right)$ : 3492; 2925; 2855; $1465 ; 1352 .{ }^{1} \mathrm{H}$ NMR see Wang et al. ${ }^{11}$ ${ }^{13} \mathrm{C}$ NMR: Table 1.

3ß-erythrodiol palmitoleate (3): Amorphous white solid (MeOH), M.p: 122-124
${ }^{\circ} \mathrm{C} . \mathrm{IR}\left(\mathrm{KBr}, \mathrm{cm}^{-1}\right): 3478,2930,2875,1463$, 1383, 1168. ${ }^{1} \mathrm{H}$ NMR: Similar data to

compounds 1a-b. ${ }^{13} \mathrm{C}$ NMR $(100 \mathrm{MHz}$, $\mathrm{CDCl}_{3}$ ): Table 1.

$3 \beta$-betulinic acid behenate, erucicate and palmitoleate (4a-c): White waxy. IR $\left(\mathrm{KBr}, \mathrm{cm}^{-}\right.$ $\left.{ }^{1}\right)$ : 3437, 2940, 2848, 1725, 1456, 1374, 1065; ${ }^{1} \mathrm{H}$ NMR (400 MHz, $\left.\mathrm{CDCl}_{3}\right) \delta: 0.89\left(3 \mathrm{H}, \mathrm{s}, \mathrm{CH}_{3}\right)$; $0.83\left(3 \mathrm{H}, \mathrm{s}, \mathrm{CH}_{3}-25\right) ; 0.84\left(3 \mathrm{H}, \mathrm{s}, \mathrm{CH}_{3}-24\right) ; 0.85$ $\left(3 \mathrm{H}, s, \mathrm{CH}_{3}-23\right) ; 0.94\left(3 \mathrm{H}, s, \mathrm{CH}_{3}-26\right) ; 0.98(3 \mathrm{H}$, s, $\left.\mathrm{CH}_{3}-27\right) ; 1.69\left(3 \mathrm{H}, \mathrm{s}, \mathrm{CH}_{3}-30\right) ; 1.25(\mathrm{nH}, \mathrm{s}, \mathrm{H}-$ $\mathrm{C}$ (n-fatty acid); $1.55-1.98$ (nH, $m, \mathrm{H}-\mathrm{C}(\mathrm{n}$-alkyl); $2.28(2 \mathrm{H}, J=7.5 \mathrm{~Hz}) ; 3.09(1 \mathrm{H}, \mathrm{m}, \mathrm{H}-19) ; 4.46$ $(1 \mathrm{H}, \mathrm{dd}, J=5.8 \mathrm{~Hz}$ and $10.2, \mathrm{~Hz}, \mathrm{H}-3) ; 4.61(1 \mathrm{H}$, br, H-29a); 4.73 (1H, br, H-29b). ${ }^{13} \mathrm{C}$ NMR (100 $\mathrm{MHz}, \mathrm{CDCl}_{3}$ ): Table 1 .

Betulinic acid (5): White solid; M.p:295-298 ${ }^{\circ} \mathrm{C}$ (dec.). IR (KBr, cm$\left.{ }^{-1}\right)$ : 3060, 1630, 880, ${ }^{1} \mathrm{H}$ NMR see Haque et al. ${ }^{12}{ }^{13} \mathrm{C}$ NMR: Table 1

\section{Results and Discussion}

The phytochemical study of the leaf ethanolic extract led to the identification of six esterified triterpenes $\mathbf{1} \mathbf{a}-\mathbf{b}, \mathbf{3}$, and $\mathbf{4} \mathbf{a}-\mathbf{c}$, while compounds $\mathbf{2}$ and $\mathbf{5}$ were obtained after the hydrolysis of the esterified triterpenes (Figure $1)$.

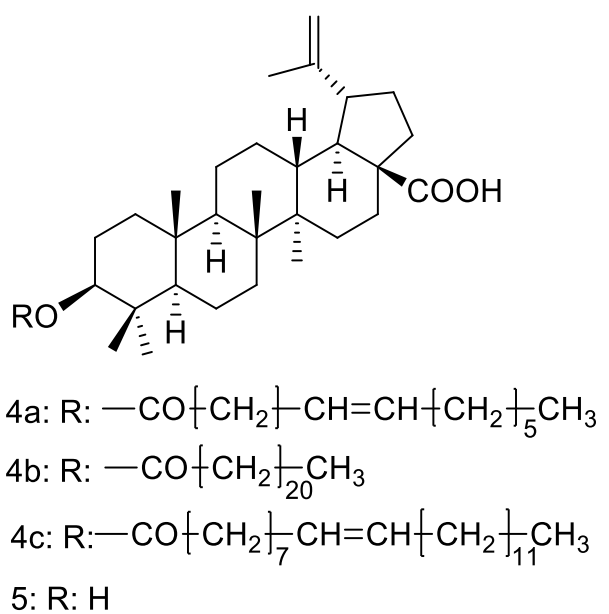

Figure 1. Chemical structures of compounds 1-5 
The structural identifications were and ${ }^{13} \mathrm{C}$ NMR (Table 1), DEPT-135, HSQC, and conducted through the analyses of the IR, ${ }^{1} \mathrm{H}, \quad \mathrm{HMBC}$ spectra.

Table 1. ${ }^{13} \mathrm{C}$ NMR $(100 \mathrm{MHz})$ chemical shifts of compounds 1-5

\begin{tabular}{|c|c|c|c|c|c|}
\hline Carbon & $\delta_{c}(1 a-b)^{a}$ & $\delta_{c}(2)^{b}$ & $\delta_{c}(3)^{a}$ & $\delta_{c}(4 a-c)^{a}$ & $\delta_{c}\left(5^{*}\right)^{b}$ \\
\hline 1 & 38.28 & 38.78 & 38.24 & 38.43 & 39.31 \\
\hline 2 & 23.81 & 23.5 & 23.53 & 28.30 & 28.33 \\
\hline 3 & 80.55 & 79.02 & 80.54 & 80.61 & 78.10 \\
\hline 4 & 37.76 & 37.75 & 37.75 & 38.41 & 39.54 \\
\hline 5 & 55.27 & 52.21 & 55.22 & 55.46 & 56,00 \\
\hline 6 & 18.25 & 18.25 & 18.23 & 18.18 & 18.83 \\
\hline 7 & 32.54 & 32.60 & 32.49 & 34.28 & 34.91 \\
\hline 8 & 39.82 & 39.81 & 39.79 & 40.74 & 41.11 \\
\hline 9 & 47.52 & 47.60 & 47.48 & 50.44 & 51.08 \\
\hline 10 & 36.84 & 36.95 & 36.81 & 37.15 & 37.52 \\
\hline 11 & 23.54 & 23.54 & 23.59 & 20.88 & 21.23 \\
\hline 12 & 122.31 & 122.38 & 122.29 & 25.48 & 26.17 \\
\hline 13 & 144.22 & 144.21 & 144.22 & 38.35 & 38.60 \\
\hline 14 & 41.74 & 41.75 & 41.71 & 42.45 & 42.92 \\
\hline 15 & 25.55 & 25.56 & 25.52 & 30.58 & 30.31 \\
\hline 16 & 22.03 & 22.04 & 21.96 & 32.17 & 32.94 \\
\hline 17 & 36.95 & 36.95 & 36.94 & 56.34 & 56.62 \\
\hline 18 & 42.36 & 42.36 & 42.34 & 49.31 & 49.81 \\
\hline 19 & 46.47 & 46.49 & 46.4 & 46.93 & 47.83 \\
\hline 20 & 30.94 & 30.94 & 30.97 & 150.36 & 151.33 \\
\hline 21 & 34.10 & 34.10 & 34.07 & 31.37 & 31.24 \\
\hline 22 & 31.04 & 31.08 & 31.04 & 37.04 & 37.60 \\
\hline 23 & 28.91 & 28.02 & 28.04 & 27.97 & 28.72 \\
\hline 24 & 15.56 & 15.56 & 15.58 & 16.05 & 16.32 \\
\hline 25 & 16.75 & 16.70 & 16.73 & 16.16 & 16.42 \\
\hline 26 & 16.80 & 16.75 & 16.78 & 16.53 & 16.40 \\
\hline 27 & 25.90 & 25.90 & 25.92 & 14.67 & 14.92 \\
\hline 28 & 69.71 & 69.70 & 69.75 & 180.75 & 178.81 \\
\hline 29 & 33.17 & 33.18 & 33.20 & 109.70 & 109.92 \\
\hline 30 & 23.58 & 23.58 & 23.46 & 19.35 & 19.54 \\
\hline $1^{\prime}$ & 173.67 & & 173.76 & 173.71 & \\
\hline $2^{\prime}$ & $34.86 / 34.82$ & & 34.07 & $34.81 / 34.86$ & \\
\hline $3^{\prime}$ & 25.18 & & 25.2 & 25.18 & \\
\hline $4^{\prime}-9^{\prime}$ & 29.69 & & 29.69 & 29.69 & \\
\hline $10^{\prime}$ & 29.69 & & 29.69 & 29.69 & \\
\hline 11-13' & 29.69 & & 29.69 & 29.69 & \\
\hline $14^{\prime}$ & 29.69 & & 31.97 & 29.69 & \\
\hline $15^{\prime}$ & 29.69 & & 21.96 & 29.69 & \\
\hline $16^{\prime}$ & 29.69 & & 14.10 & 29.69 & \\
\hline $17^{\prime}-19^{\prime}$ & 29.69 & & & 29.69 & \\
\hline $20^{\prime}$ & 31.92 & & & 31.92 & \\
\hline $21^{\prime}$ & $22.57 / 22.67$ & & & $22.57 / 22.67$ & \\
\hline $22^{\prime}$ & $14.03 / 14.09$ & & & $13.88 / 14.02 / 14.08$ & \\
\hline
\end{tabular}

${ }^{\mathrm{a}}\left(\mathrm{CDCl}_{3}\right),{ }^{\mathrm{b}}\left(\mathrm{CDCl}_{3}\right.$ and $\left.\mathrm{Py}-\mathrm{d} 5\right), *(\mathrm{Py}-\mathrm{d} 5)$ literature. 
The ${ }^{1} \mathrm{H}$ NMR spectrum of the mixture of compounds $\mathbf{1} \mathbf{a}-\mathbf{b}$ presented six singlets between $\delta_{\mathrm{H}} 0.86$ and 9.95 , characteristic of the seven methyl groups; an intense singlet at $\delta_{\mathrm{H}} 1.25$, characteristic of alkyl chain methylene hydrogen, and a triplet at $\delta_{\mathrm{H}} 2.28(2 \mathrm{H}, J=7.8$ $\mathrm{Hz}$ ), referent to the $\mathrm{H}-\mathrm{2}^{\prime}$ hydrogen, neighboring $\mathrm{C}=\mathrm{O}$ of the triterpene ester. The signal at $\delta_{\mathrm{H}} 4.51(1 \mathrm{H}, \mathrm{m}, \mathrm{H}-3)$ was attributed to the oxymethinic hydrogen at $\mathrm{C}-3$. The presence of two defined doubles at $\delta_{\mathrm{H}} 3.21$ $(1 \mathrm{H}, \mathrm{d}, J=10.9 \mathrm{~Hz})$ and $\delta_{\mathrm{H}} 3.54(1 \mathrm{H}, \mathrm{d}, J=10.9$ $\mathrm{Hz}$ ), characteristic of coupled oxymethylene hydrogens and a triplet at $\delta_{H} 5.17(1 \mathrm{H}, \mathrm{t}, J=3.2$ $\mathrm{Hz})$, suggests the presence of the erythrodiol nucleus. ${ }^{11}$ The correlations $\mathrm{H}-\mathrm{C}$ were confirmed in the HSQC experiment. The correlations observed in the $\mathrm{HMBC}$ experiment (Figure 2) allow the assignment of the double bond at $\mathrm{C}-12$ and $\mathrm{C}-13$, through the correction of the signal at $\delta_{\mathrm{H}} 5.17$ with the signals at $\delta_{c} 47.52$ (C-9), 23.54 (C-11), and 42.36 (C-18). The presence of the oxymethylene group at C-28 was confirmed through the correlation between $\delta_{\mathrm{H}} 3.54$ and $\delta_{H} 3.21$ with $\delta_{C} 22.03$ (C-16) and 31.04 (C-22). The correlation of the signal at $\delta_{\mathrm{H}} 4.51$ with $\delta_{\mathrm{C}}$ 38.28 (C-1), 23.81 (C-2), 28.91 (C-23), 15.56 (C$24)$, and 173.67 (C-1') confirms the triterpene esterification at the $\mathrm{C}-3$ position.

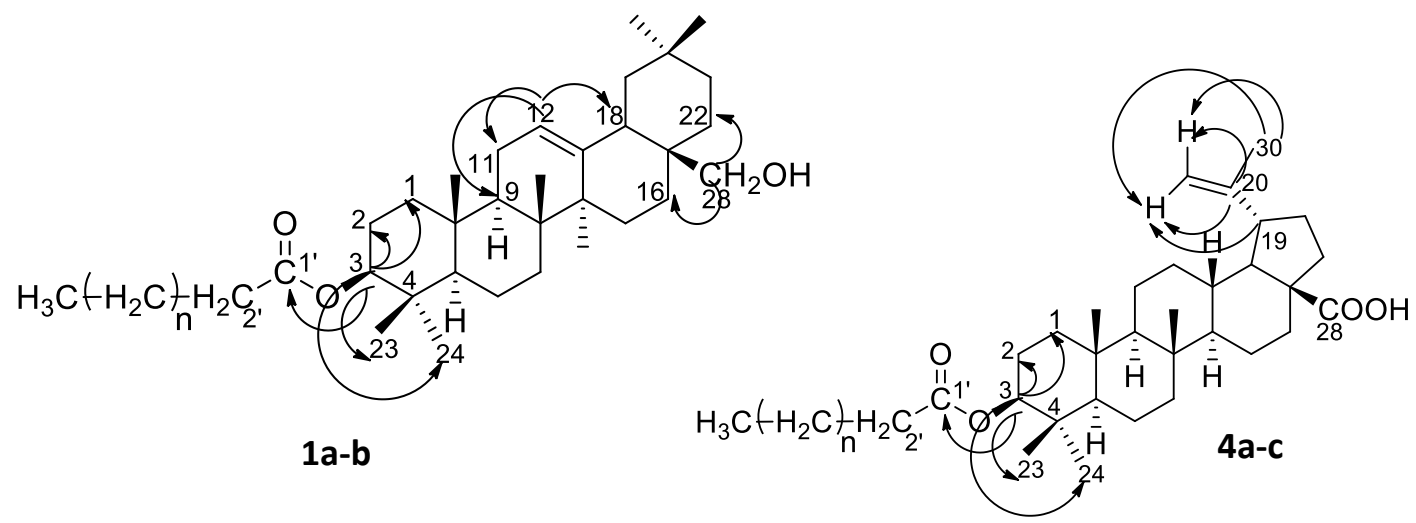

Figure 2. Main correlations observed for $\mathrm{HMBC}_{\mathrm{s}}(\mathrm{H} \rightarrow \mathrm{C})$ from compounds $\mathbf{1} \mathbf{a}-\mathbf{b}$ and $\mathbf{4 a - c}$

To identify the long chain fatty acid, the mixture of the compounds $\mathbf{1} \mathbf{a}-\mathbf{b}$ was transesterified with $\mathrm{MeOH} / \mathrm{MeONa}$. The GC analysis of the $\mathrm{CHCl}_{3}$ phase of this reaction indicated the presence of methyl behenate and methyl erucate. Thus, the compounds 1ab are a mixture of $3 \beta$-erythrodiol behenate and erucate. From the aqueous phase, a white solid was obtained (compound 2); its structural elucidation was based on $I R,{ }^{1} \mathrm{H}$ NMR, ${ }^{13} \mathrm{C}$ NMR (proton decoupled and DEPT135) analysis and by comparison with erythrodiol spectral data. ${ }^{11}$

The $I R,{ }^{1} \mathrm{H}$, and ${ }^{13} \mathrm{C}$ NMR data (Table 1), DEPT-135, HSQC, and HMBC from compound 3 suggest the presence of esterified erythrodiol, which is similar to the mixture of compounds $\mathbf{1 a}-\mathbf{b}$. In a similar manner, the fatty acid chain was characterized through the reaction from the transesterification of this compound. The GC analysis indicated the presence of methyl palmitoleate. Thus, compound $\mathbf{3}$ is $3 \beta$-erythrodiol palmitoleate. The mixture of compounds $\mathbf{1} \mathbf{a}-\mathbf{b}$ and compound $\mathbf{3}$ are being reported for the first time in the Pouteria genus. Esterified erythrodiol with long chain fatty acid (without the identification of the long chain) was isolated from $P$. campechiana, ${ }^{8}$ and from $P$. torta leaves was isolated erythrodiol palmitate. ${ }^{9}$

The spectrum of ${ }^{1} \mathrm{H}$ NMR of the mixture of compounds 4 a-c presented six signals between $\delta_{\mathrm{H}} 0.83$ and 1.69 , characteristics of the six methyl groups, an intense singlet at $\delta_{\mathrm{H}}$ 
1.25, characteristic of an alkyl chain methylene hydrogen and a triplet at $\delta_{\mathrm{H}} 2.28$ $(2 \mathrm{H}, J=7.5 \mathrm{~Hz})$, equivalent to the $\mathrm{H}-2^{\prime}$ hydrogen, neighboring the ester $\mathrm{C}=\mathrm{O}$. The signal at $\delta_{H} 4.46(1 \mathrm{H}, \mathrm{dd}, J=5.8$ and $J=10.2$ $\mathrm{Hz}$ ) was attributed to $\mathrm{H}-3$ of the oxymethinic hydrogen, suggesting a compound containing $\mathrm{C}-3$ esterified. The presence of two broad singlets at $\delta_{\mathrm{H}} 4.46(1 \mathrm{H})$ and $\delta_{\mathrm{H}} 4.73(1 \mathrm{H})$ was assigned to terminal olefin hydrogens, suggesting the presence of a betulinic acid nucleus. ${ }^{12}$ The main correlations observed in the $\mathrm{HMBC}$ experiment (Figure 2) confirmed the presence of the terminal double bond at C-29 and C-20, through the correlations of signals at $\delta_{H} 4.73$ and $\delta_{H} 4.61$ with $\delta_{C} 19.35$, (C30), 150.36 (C-20), and 46.93 (C-19). The correlation of the signal at $\delta_{\mathrm{H}} 4.46$ with signals at $\delta_{c} 38.43$ (C-1), 28.30 (C-2), 27.97 (C-23), 16.05 (C-24), and 173.71 (C-1') confirmed the esterification in the $\mathrm{C}-3$ carbon. The correlation of the signal at $\delta_{\mathrm{H}} 3.09(1 \mathrm{H}, \mathrm{m}, \mathrm{H}-$ 19), with $\delta_{c} 19.35$ (C-30), 31.37 (C-21), 49.31 (C-18), and 109.70 (C-29), confirmed the position of the olefin at C-20 and C-29. These chemical shifts are compatible with that reported for the esterified betulinic acid with the long chain fatty acid. ${ }^{8}$

The mixture of compounds $4 a-c$ was transesterified with $\mathrm{MeOH} / \mathrm{MeONa}$. The GC analysis indicated the presence of methyl behenate, methyl eurucate, and methyl palmitoleate.

Thus, the compounds $4 \mathrm{a}-\mathrm{c}$ are a mixture of $3 \beta$-betulinic acid behenate, erucate, and palmitoleate, which is being reported for the first time in this study. Ragasa et al. isolated a mixture of esterified betulinic acid with long chain acid from P. campechiana; however, the alkyl chain was not identified. ${ }^{8}$

From the aqueous phase of the transesterifictaion reaction, a solid was obtained, compound $\mathbf{5}$. Its structural elucidation was based on the analyses performed in IR, ${ }^{1} \mathrm{H}$, and ${ }^{13} \mathrm{C}$ NMR spectra, as compared to assignments for the betulinic acid. ${ }^{12}$

\section{Conclusions}

The extract from $P$. macahensis leaves is rich in triterpenes esterified with long chain fatty acids. This occurrence may well be associated with the localization of individual species in the Atlantic Rainforest, in a sandy terrain and in a region with constant sunshine.

\section{Acknowledgements}

We wish to thank the collaborations from the Bioma Group for their analyses in IR, the Fundação de Amparo a Pesquisa do Estado da Bahia (FAPESB) for their concession of a Masters' Degree grant, and the UESC postgraduate program in chemistry (PPGQUIM).

\section{References}

${ }^{1}$ a) Fabris, L. C.; Peixoto, A. L. Sapotaceae das Restingas do Espírito Santo, Brasil. Rodriguesia 2013, 64, 263. [CrossRef] b) Silva, C. A. M.; Simeoni, L. A; Silveira, D. Genus Pouteria: Chemistry and biological activity. Revista Brasileira de Farmacognosia 2009, 19, 501. [CrossRef]

2 Pennington, T. D. The genera of Sapotaceae, Royal Botanic Gardens, Kew: Chicago, 1991.

${ }^{3}$ Alves-Araújo, A.; Alves, M. Checklist of Sapotaceae in northeastern Brazil. Check List 2013, 9, 59. [CrossRef]

${ }^{4}$ Wandji, J.; Tillequin, F.; Mulholland, D. A.; Wansi, J. D.; Fomum, T. Z.; Fuendjiep, V.; Libot, F.; Tsabang, N. Acid esters of triterpenoids and steroid glycosides from Gambeya africana. Planta Medica 2002, 68, 822. [PubMed]

${ }^{5}$ Rhourri-Frih, B.; Renimel, I.; Chaimbault, P.; Andre, P.; Herbette, G.; Lafosse, M. Pentacyclic triterpenes from Manilkara bidentata resin. Isolation, identification and biological properties. Fitoterapia 2013, 88, 101. [PubMed] 
${ }^{6}$ Fernandes, C. P.; Corrêa, A. L.; Lobo, J. F. R.; Caramel, O. P.; De Almeida, F. B.; Castro, E. S.; Souza, K. F. C. S.; Burth, P.; Amorim, L. M. F.; Santos, M. G.; Ferreira, J. L. P.; Falcão, D. Q.; Carvalho, J. C. T.; Rocha, L. Triterpene esters and biological activities from edible fruits of Manilkara subsericea (Mart.) dubard, Sapotaceae. Biomed Research International 2013, 2013:280810. [CrossRef] [PubMed].

${ }^{7}$ Medeiros, F. A.; Tese de Doutorado, Universidade Federal da Paraiba, 2008. [Link]

${ }^{8}$ Ragasa, Y.; Labaclado, L. M.; Rideout, J. A. Triterpenes and Sterol from Pouteria campechiana. The Manila Journal of Science 2011, 2, 1. [Link]

${ }^{9}$ Lopes, K. S. E.; Dissertação de Mestrado, Universidade de Brasília, 2005. [Link]
${ }^{10}$ Mendes, C. C.; Cruz, F. G.; David, J. M.; Nascimento, I. P.; David, J. P. Triterpenos Esterificados com Ácidos Graxos e Ácidos Triterpênicos Isolados de Byrsonima microphylla. Quimica Nova 1999, 22, 185. [CrossRef]

$11{ }^{11}$ Wang, B.; Li, G. Q.; Guan, H. S.; Yang, L. Y.; Tong, G. Z. A new erythrodiol triterpene fatty ester from Scorzonera mongolica. Acta Pharmaceutica Sinica 2009, 44, 1258. [PubMed]

${ }^{12}$ Haque, E.; Shekhar, H. U.; Mohamad, A. U.; Rahman, H.; Islam, a K. M. M.; Hossain, M. S. Triterpenoids from the Stem Bark of Avicennia officinalis. Dhaka University Journal of Pharmaceutical Sciences 2006, 15, 53. [CrossRef] 